\title{
Increased serotonin concentration and tryptophan hydroxylase activity in reproductive organs of copulator males: a case of adaptive plasticity
}

\author{
Ana Ingrid Pichardo ${ }^{1 \star}$, José L.Tlachi-López ${ }^{2 \star}$, Francisco Jiménez-Trejo ${ }^{3 *}$, Alma L. Fuentes-Farías ${ }^{4 *}$, \\ Armida Báez-Saldaña ${ }^{1}$, María L. Molina-Cerón ${ }^{1}$, Gabriel Manjarréz-Gutiérrez ${ }^{5}$, \\ Gabriel Gutiérrez-Ospina ${ }^{1 *}$, Rosa Angélica Lucio ${ }^{2 *}$
}

\footnotetext{
${ }^{1}$ Departamento de Biología Celular y Fisiología, Instituto de Investigaciones Biomédicas, Universidad Nacional Autónoma de México, Ciudad Universitaria 04510, México, D.F., México;

${ }^{2}$ Centro Tlaxcala de Biología de la Conducta, Universidad Autónoma de Tlaxcala, Carretera Tlaxcala-Puebla km 1.5 s/n, Loma Xicotencatl, 90062, Tlaxcala, México;

${ }^{3}$ Departamento de Farmacología, Facultad de Medicina, Universidad Nacional Autónoma de México, Ciudad Universitaria 04510, México, D.F., México;

${ }^{4}$ Laboratorio de Invertebrados y Ecofisiología, Facultad de Biología, Universidad Michoacana de San Nicolás de Hidalgo, Ciudad Universitaria 58030, Michoacán, México;

${ }^{5}$ Unidad de Investigación Biomolecular, Hospital de Cardiología, Centro Médico Nacional Siglo XXI, Instituto Mexicano del Seguro Social 06720, México, D.F., México.

Email: 1ucioral@yahoo.com.mx; gabo@correo.biomedicas.unam.mx
}

Received 27 December 2010; revised 19 February 2011; accepted 27 February 2011.

\begin{abstract}
Individual male rats may systematically display or not copulatory behavior when paired with receptive females. Although these phenotypes are associated with differences in brain organization and function, they might also do so at the level of the reproductive organs. We then used high performance liquid chromatography to quantify serotonin concentration and the activity of tryptophan hydroxylase in the reproductive organs of copulator and non-copulator males. Sexual behavior display was compared between groups and parameters of fertility and reproductive fitness were determined for copulator males. Copulator males had higher concentrations of serotonin in the epididymis, testicle and ventral prostate than their non-copulator counterparts, as it was found for epididymal and testicular tryptophan hydroxylase activity. However, preliminary data shows that serotonin elevation occurs in copulator males only until they have accumulated several sexual encounters, so it might be a response to genital gratification or sexual rewarding. Interestingly, only epididymal serotonin concentration correlated with reproductive fitness, offspring number, mating success and seminal plug volume in copulator males. Our results support that copulator and non-copulator male rats feature a
\end{abstract}

\footnotetext{
-These authors contributed equally to the present work.
}

phenotype-specific serotoninergic tone in the epididymis, testicle and ventral prostate gland. The observation documenting that epididymal serotonin concentration correlated with parameters that monitor male fertility and reproductive fitness in copulator males predicts that epididymal factors increase their chances of parenting offspring.

Keywords: Sexual Accessory Glands; Copulation; Indolamines; Seminal Fluid; Seminal Plug; Successful Mating; Reproductive Fitness

\section{INTRODUCTION}

Copulatory or consummatory behavior in male rats is displayed as a stereotyped motor pattern that comprises mounts, intromissions and ejaculation [1]. Although this pattern suits well the majority of male rats, a small percentage of them exhibit either none or incomplete copulatory behavior when repeatedly paired with sexually receptive females [2]. Even though the origin of the rat's copulator and non-copulator phenotypes is unclear, evidence showing differences in motivational and precopulatory behaviors, detection of sexually significant odors, number of hypothalamic and amygdaline neurons containing androgen or estrogen receptors and levels of hypothalamic aromatase activity between both rat groups [3-6] suggests that these are innate phenotypes.

The display of successful sexual behavioral responses 
depends upon the ability of each male to accurately assess his internal physiological state and precisely match it with his sexual/reproductive expectations/output under a given context [1]. It is then likely that copulator and non-copulator rat males also feature distinct traits in their genital organs. Accordingly, the present work evaluated possible differences of the serotoninergic tone in reproductive organs of males displaying or not normal copulatory behavior. Studying the serotoninergic tone seems an adequate election because this parameter shifts across genital/reproductive organs as sexual maturation progresses, with reproductive status or photoperiod length and along the breeding season in various different species [7-9]. Also genital serotonin modulates, among other important reproductive processes, ejaculation, seminiferous tubule fluid transit, production and clearance, sexual accessory glands contraction, epididymal fluid composition, testicular steroidogenesis and spermatogenesis [10-15].

\section{MATERIALS AND METHODS}

\subsection{Animals}

Sexually inexperienced adult male Wistar rats (Rattus norvegicus; 90 days of age/300 grams of body weight; $n$ $=22$ ) were chosen randomly from the regular stock of the colony raised at the animal facility of the Instituto de Investigaciones Biomédicas, Universidad Nacional Autónoma de México. Males were screened for their copulatory abilities and grouped as copulators or noncopulators (see below). Male rats were then caged in clusters of three or four individuals of the same class. The animals were kept in rooms with constant temperature $\left(22^{\circ} \mathrm{C} \pm 1^{\circ} \mathrm{C}\right)$ and humidity under an inverted light cycle (12:12 hours, lights off at 7:00 hrs). Food (2018S Pellets, Harlan) and water were available ad libitum. Animal handling and experimentation followed the Guidelines for the Care and Use of Laboratory Animals published by the National Institutes of Health. Local Animal Right's Committees approved all of the animal protocols described in this work.

\subsection{Male Selection}

Male rats were classified as copulators $(n=10)$ or non-copulators $(n=13)$ after analyzing their sexual performance along four consecutive copulatory encounters with receptive, ovariectomized female rats [16]. Copulator males displayed fully the copulatory pattern in every encounter within a 15 minute period of having being initiated the testing session. In contrast, non-copulator males executed incomplete copulatory behavior in every encounter within a 45 minute period of having being started the testing trial. Mounting, intromission and ejaculation latencies and the number of mounts and intromissions associated with pelvic thrusting were recorded for each male during each encounter. The hit rate, an index taken to reflect erectile potential, was also estimated [17].

\subsection{Semen and Seminal Plug Evaluation in Copulator Males}

Semen and seminal plug quality was evaluated only in copulator males $(n=7)$ because non-copulators never reached the ejaculatory threshold. These analyses were carried out in ejaculates withdrawn from the uterine horns and in seminal plugs released from the vagina of the inseminated females used during the third and fourth copulatory encounters, as described elsewhere [16]. The parameters obtained for copulator males were comparable to those reported previously for sexually experienced rat males of the same strain (see Tables 1 and 2 and reference [16]).

\subsection{Fertility and Reproductive Fitness in Copulator Males}

To evaluate individual reproductive fitness in copulator males $(n=7)$, each male was paired in a regular enclosure with a naturally receptive, intact female during 48 hours, fifteen days after the last copulatory encounter. Reproductive encounters were repeated four times for each copulator male every 15 days. By the end of each reproductive encounter, the couple was separated and the dam caged individually and visually inspected every day first to corroborate pregnancy and then to assure normal pregnancy progression. After delivery, the offspring remained with the mother until weaning by postnatal day 28 when living pups were counted. Individual reproductive fitness was then estimated by calculating what we called the reproductive fitness index. This parameter resulted from summing up the number of opportunities to mate, the number of pregnancies achieved and the number of living pups by the end of weaning divided by 47 . The constant in the divisor represents the sum of the total number of mating opportunities, pregnancies and living pups of the male with the greatest reproductive efficacy. This constant then defines the conditions that each male would have must achieved to assure maximal reproductive outcome under the experimental paradigm tested.

\subsection{Serotonin Concentration and Tryptophan Hydroxylase Activity in Copulator Males}

Copulator $(n=7)$ and non-copulator males $(n=7)$ were sacrificed immediately after the last reproductive or copulatory encounter, respectively. The rats were sacrificed by overdosing pentobarbital administered intraperitoneally ( $26 \mathrm{mg} / \mathrm{Kg}$ of body weight). Then, the right reproductive organs (testicle and epididymis) and accessory sexual glands (ventral prostate, seminal vesicle, 
Table 1. Copulatory parameters of copulator (C) and non-copulator males (NC).

\begin{tabular}{|c|c|c|c|c|c|c|c|c|c|c|c|c|}
\hline \multirow[t]{2}{*}{ Male } & \multicolumn{2}{|c|}{$\begin{array}{l}\text { Mounting } \\
\text { Latency } \\
\text { (seconds) }\end{array}$} & \multicolumn{2}{|c|}{$\begin{array}{c}\text { Intromission } \\
\text { Latency } \\
\text { (seconds) }\end{array}$} & \multicolumn{2}{|c|}{$\begin{array}{c}\text { Ejaculation } \\
\text { Latency } \\
\text { (seconds) }\end{array}$} & \multicolumn{2}{|c|}{$\begin{array}{l}\text { Mounts } \\
\text { Number }\end{array}$} & \multicolumn{2}{|c|}{$\begin{array}{c}\text { Intromission } \\
\text { Number }\end{array}$} & \multicolumn{2}{|c|}{ Hit Rate } \\
\hline & C & NC & C & NC & C & NC & C & NC & C & NC & C & NC \\
\hline 1 & 18 & 16 & 26 & - & 902 & - & 26 & 36 & 24 & - & 0.48 & - \\
\hline 2 & 15 & 32 & 115 & 183 & 1271 & - & 79 & 56 & 24 & 8 & 0.23 & 0.21 \\
\hline 3 & 16 & 22 & 92 & - & 532 & - & 13 & 39 & 16 & - & 0.55 & - \\
\hline 4 & 37 & 12 & 58 & - & 1190 & - & 29 & 28 & 22 & - & 0.43 & - \\
\hline 5 & 21 & 14 & 23 & 480 & 558 & - & 13 & 42 & 19 & 9 & 0.59 & 0.17 \\
\hline 6 & 21 & 21 & 101 & - & 928 & - & 52 & 16 & 27 & - & 0.34 & - \\
\hline 7 & 10 & 18 & 87 & - & 1762 & - & 81 & 10 & 22 & - & 0.21 & - \\
\hline
\end{tabular}

Table 2. Parameter of the seminal fluid in copulator males*.

\begin{tabular}{|c|c|c|c|c|c|c|c|}
\hline \multirow[b]{2}{*}{ Male } & \multicolumn{3}{|c|}{$\begin{array}{c}\text { Macroscopic Seminal Fluid } \\
\text { Parameters }\end{array}$} & \multicolumn{4}{|c|}{ Microscopic Seminal Fluid Parameters } \\
\hline & color & $\begin{array}{l}\text { viscosity } \\
(\mathbf{m m})\end{array}$ & $\mathbf{p H}$ & $\begin{array}{c}\text { sperm motility } \\
(\%)\end{array}$ & $\begin{array}{c}\text { sperm viability } \\
(\%)\end{array}$ & $\begin{array}{c}\text { sperm morphology } \\
(\%)\end{array}$ & $\begin{array}{l}\text { sperm concentration } \\
\text { (millions/milliliter) }\end{array}$ \\
\hline 1 & white & 2.5 & 7.5 & 20.0 & 46 & 97 & 15.5 \\
\hline 2 & white & 1 & 8 & 43.2 & 69 & 100 & 4.0 \\
\hline 3 & white & 0.5 & 8 & 57.5 & 62 & 98 & 16.0 \\
\hline 4 & white & 1.5 & 8 & 47.0 & 51 & 99 & 7.2 \\
\hline 5 & white & 2 & 7.5 & 72.5 & 54 & 100 & 17.2 \\
\hline 6 & white & 1.5 & 8 & 37.7 & 55 & 98 & 7.2 \\
\hline 7 & white & 1.5 & 8 & 63.0 & 63 & 100 & 24.2 \\
\hline
\end{tabular}

*Values of the third and fourth copulatory encounters were averaged.

coagulating gland and bulbourethral gland) of copulator and non-copulator males were excised and processed to determine serotonin concentrations (least detectable dose $5 \mathrm{pg} / \mu \mathrm{l}$ ) following the protocol published by [7]. The left reproductive organs and accessory sexual glands were used to determine the activity of tryptophan hydroxylase (TPH) according to the protocol described by [7]. Results for serotonin concentration are expressed in $\mathrm{pg} / \mathrm{mg}$ of tissue and for TPH activity in nMol of 5-hydroxytryptophan produced/milligram of protein/ hour.

\subsection{Statistical Analysis}

Differences of serotonin concentration and TPH activity among various reproductive organs of copulator and non-copulator males were evaluated by using the Mann-Whitney U tests (Statistica 7.0) setting the significance level at $\mathrm{p}<0.05$. Correlations among fertility parameters, reproductive fitness and serotonin concentration in different organs were evaluated by using Pearson's Coefficient analyses (Statistica 7.0).

\section{RESULTS}

\subsection{Copulatory Behavior in Copulator and Non-Copulator Males}

Copulator males showed the complete repertoire of copulatory movements, right from the first copulatory encounter. In sharp contrast, non-copulator males displayed incomplete copulatory motor patterns throughout the encounters. Although mounting latency tended to be similar between groups, intromission latency roughly quadruplicated in non-copulator males (Table 3). The number of mounts and intromissions, as well as the hit rate, were found decreased in non-copulator males (Table 3$)$.

\subsection{Serotonin Concentration and TPH Activity in the Reproductive Organs of Copulator and Non-Copulator Males}

The concentration of serotonin and TPH activity in the reproductive organs of copulator and non-copulator males are shown in Figures 1 and 2, respectively. Al 
Table 3. Parameters of the seminal plugs in copulator males*.

\begin{tabular}{|c|c|c|c|c|c|c|c|c|}
\hline \multicolumn{6}{|c|}{ Macroscopic Seminal Plug Parameters } & \multicolumn{3}{|c|}{ Microscopic Seminal Plug Parameters } \\
\hline Male & Consistency & $\begin{array}{l}\text { weight } \\
\text { (mg) }\end{array}$ & $\begin{array}{l}\text { length } \\
(\mathrm{mm})\end{array}$ & $\begin{array}{l}\text { width } \\
\text { (mm) }\end{array}$ & $\begin{array}{c}\text { volume } \\
\left(\mathrm{mm}^{3}\right)\end{array}$ & $\begin{array}{c}\text { spermatozoa } \\
(\%)\end{array}$ & $\begin{array}{l}\text { flagella } \\
\quad(\%)\end{array}$ & $\begin{array}{r}\text { heads } \\
(\%)\end{array}$ \\
\hline 1 & hardened & 90.10 & 10.45 & 4.91 & 72.88 & 1.76 & 32.98 & 65.25 \\
\hline 2 & hardened & 100.72 & 11.33 & 4.32 & 55.05 & 1.22 & 20.35 & 78.42 \\
\hline 3 & hardened & 105.15 & 12.0 & 5.21 & 87.50 & 0.87 & 36.44 & 62.68 \\
\hline 4 & hardened & 75.67 & 9.78 & 4.29 & 46.74 & 2.78 & 13.66 & 83.55 \\
\hline 5 & hardened & 110.82 & 13.9 & 4.40 & 73.65 & 2.67 & 32.95 & 64.37 \\
\hline 6 & hardened & 85.14 & 11.52 & 4.11 & 51.87 & 3.19 & 27.99 & 68.81 \\
\hline 7 & hardened & 95.55 & 15.84 & 4.28 & 74.45 & 3.82 & 22.53 & 73.64 \\
\hline
\end{tabular}

*Values of the third and fourth copulatory encounters were averaged.

though serotonin was readily quantified in all of the reproductive organs, TPH activity was only detected in samples from the testicle, epididymis and seminal vesicle in both animal groups. In the testicle and epididymis, the concentration of serotonin and TPH activity were significantly higher in copulator than in non-copulator males. In contrast, the values obtained for both parameters in the seminal vesicle, coagulating gland and bulbourethral gland were similar between groups (data for coagulating and bulbourethral glands are not shown). Interestingly, even though the ventral prostate showed significantly higher concentrations of serotonin in copulator than in non-copulator males, TPH activity in this organ was equally low in both groups of rats. The increment of the serotoninergic tone in the testicles, epididymis and ventral prostate in copulator males appears not to be an inherent trait because preliminary observations show that serotonin concentrations are not elevated in the testicle and epididymis of this rat group by the end of the copulatory encounters (Figure 3 ).

\subsection{Relationships among Serotonin Concentration and Tryptophan Hydroxylase Activity in Reproductive Organs with Reproductive Fitness, Fertility and Sexual Performance in Copulator Males}

Pearson's coefficient analyses were used to evaluate possible correlations among serotonin concentration or TPH activity in the testes, epididymis or ventral prostate with reproductive, fitness, fertility or sexual performance. Correlations were only significant for epididymal serotonin and reproductive fitness (Figure 4), number of pups sired, successful matings and seminal plug volume (Figure 5).

\section{DISCUSSION}

Male rats may be either copulators or non-copulators. Although these phenotypes are characterized by distinct neurophysiological attributes [3-6], we did not know whether they also comprise characteristic morphofunctional traits at the genital level. In this work, we report data that shows that copulator males have elevated testicular, epididymal and prostatic serotonin concentration and TPH activity as compared with non-copulator males. These differences seem specifically ascribed to the copulator phenotype because both parameters were comparable in the seminal vesicles, coagulating and bulbo-urethral glands of copulator and non-copulator males. Although differences in copulatory abilities among male rats may be inherent, our results suggest that the increment of the serotoninergic tone in some reproductive organs of copulator males is an acquired trait. Indeed, the increased testicular, epididymal and prostatic serotonin concentration and TPH activity were not observed in copulator males that were sacrificed by the end of the copulatory encounters. Although the mechanism by which the increment of the serotoninergic tone occurs in copulator males is unclear, dynamic adjustments (i.e., adaptive plasticity) of the morpho-physiological properties of genital organs in response to social cues, sexual experience, genital gratification and/or sexual rewarding may be involved since they have been previously documented in rodents [1,18-20]. But ¿do increments of testicular, epididymal and prostatic serotonin concentration or TPH activity have any reproductive value for copulator males? Our study suggests that at least at the epididymal level, increased serotonin concentrations improves the possibility of a copulator male to achieve paternity. Indeed, resynthesized in this organ. 


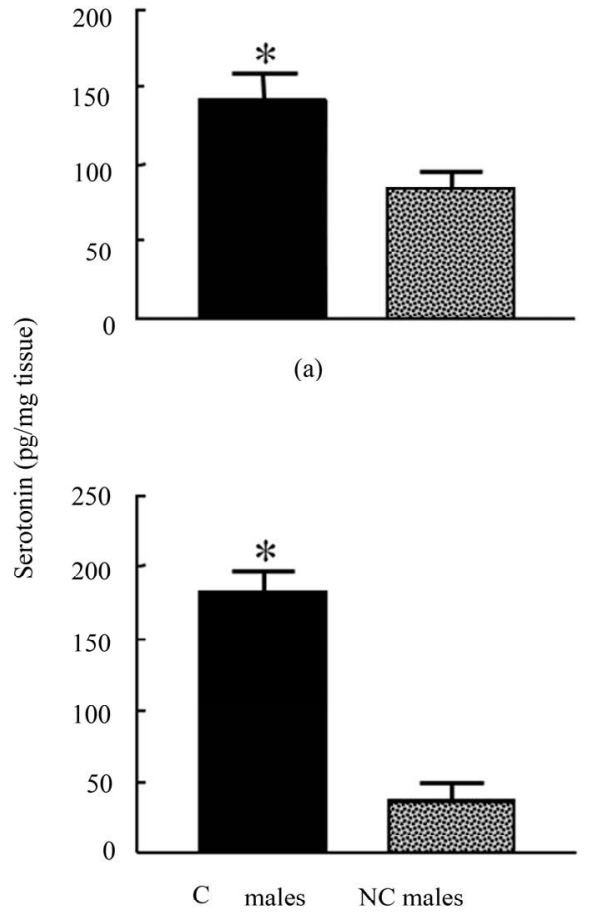

(c)

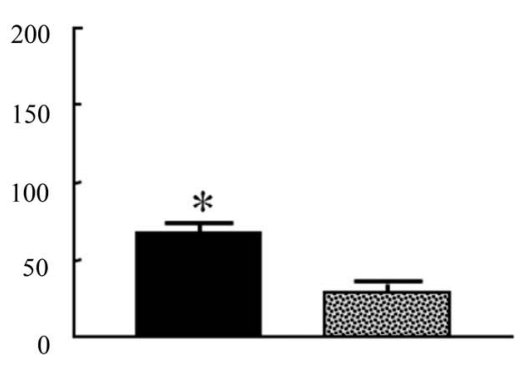

(b)

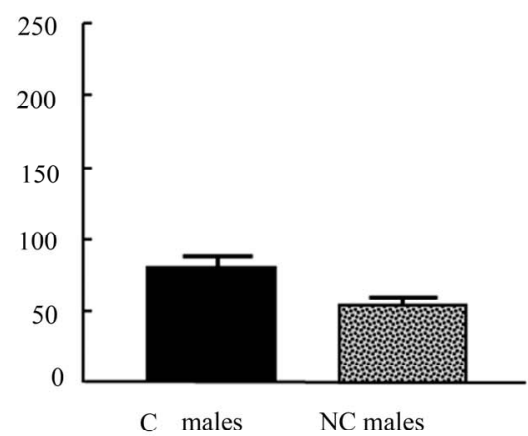

(d)

Figure 1. Bar graphs that show the concentration of serotonin in the testicle (a), epididymis (b), ventral prostate gland (c) and seminal vesicle (d) of copulator (c) and non-copulator (NC) male rats. U Mann Whitney *P $<0.05$ versus NC males.

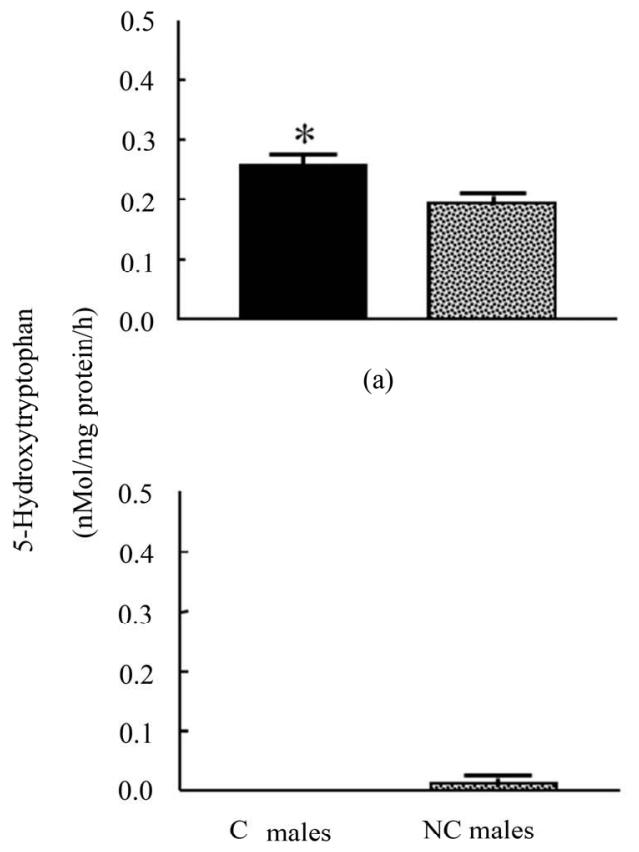

(c)

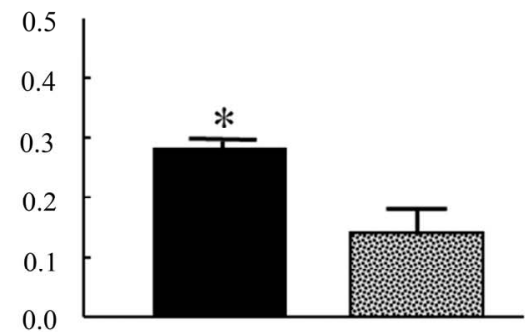

(b)

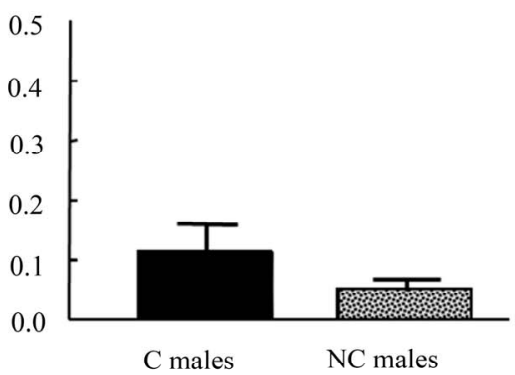

(d)

Figure 2. Bar graphs that show the levels of tryptophan hydroxylase activity in the testicle (a), epididymis (b), ventral prostate gland (c) and seminal vesicle (d) of copulator (c) and non-copulator (NC) male rats. U Mann Whitney $* \mathrm{P}<0.05$ versus $\mathrm{NC}$ males. 


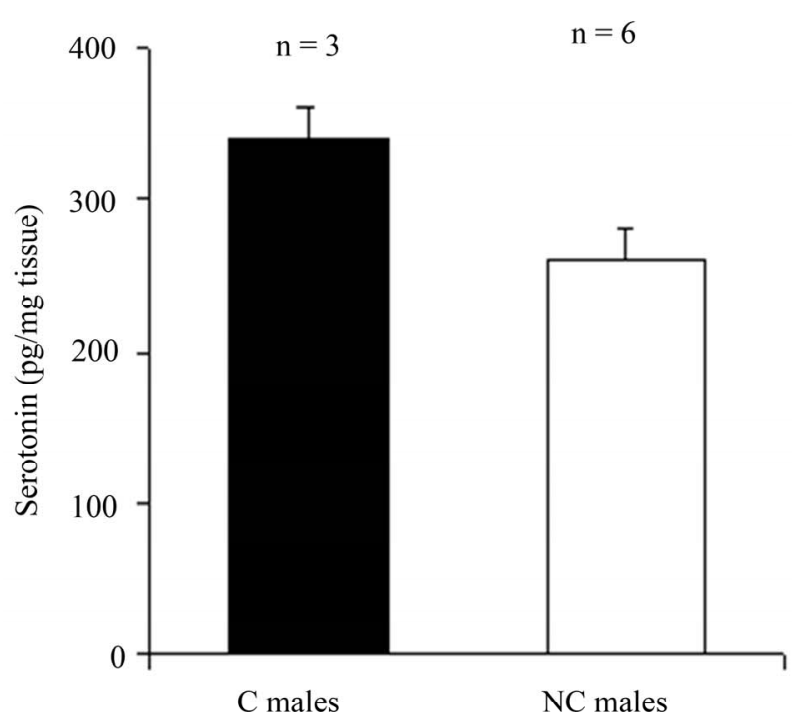

(a)

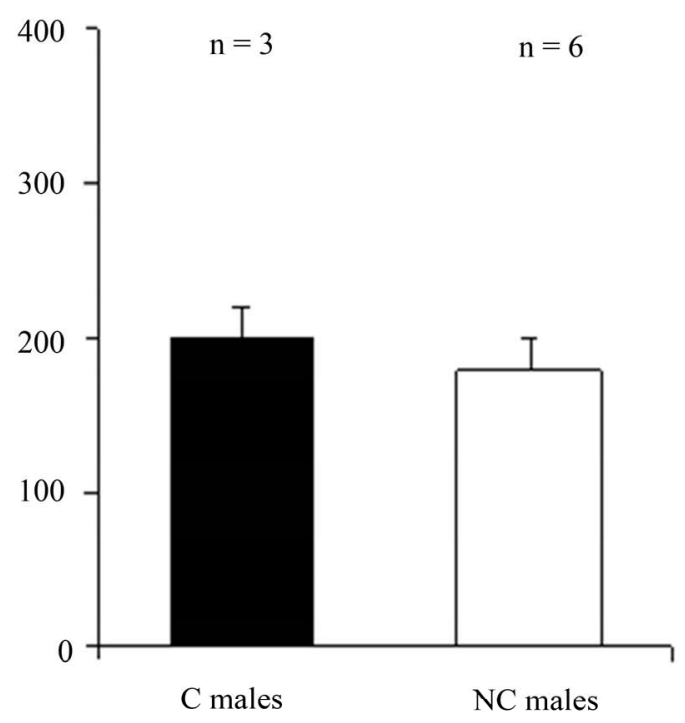

(b)

Figure 3. Bar graphs that depict the concentration of serotonin in the testicle (A) and epididymis (B) of copulator (C) and non-copulator (NC) male rats as determined through ELISA (EIA kit, ALPCO Diagnostics, Salem, NH). Briefly, after weighing each organ, tissue samples were homogenized in Glycine- $\mathrm{HCl}$ buffer $\mathrm{pH} 2.2$ added with $0.1 \%$ (w/v) of ascorbic acid $\left(10 \mathrm{~mL}\right.$ of buffer $/ \mathrm{g}$ of tissue), and centrifuged at $16000 \mathrm{~g}$ for 10 minutes at $4^{\circ} \mathrm{C}$. The supernatants were collected, light-protected and stored at $4^{\circ} \mathrm{C}$ until their use. The day of experiment samples were tempered and acylated during 30 minutes at room temperature. Then, they were incubated with primary polyclonal antibodies raised against serotonin for 20 hours at $4^{\circ} \mathrm{C}$. After three gently washes, the secondary antibodies coupled to peroxidase were added for 30 minutes at room temperature. Peroxidase activity was revealed using DAB and hydrogen peroxide for 15 minutes at room temperature. Serotonin was quantified using a microplate reader set at $450 \mathrm{~nm}$ and the reference wavelength was set between $620 \mathrm{~nm}$ and $650 \mathrm{~nm}$. The calibration curve was elaborated using known concentrations of serotonin $(0,0.0975,0.325$, $0.975,3.25$ and $16.25 \mathrm{ng} / \mathrm{ml})$. Non-significant differences were documented between groups.

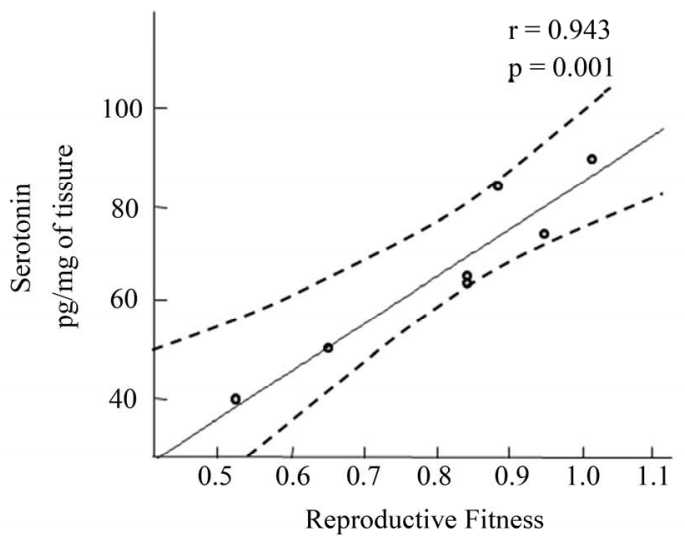

(a)

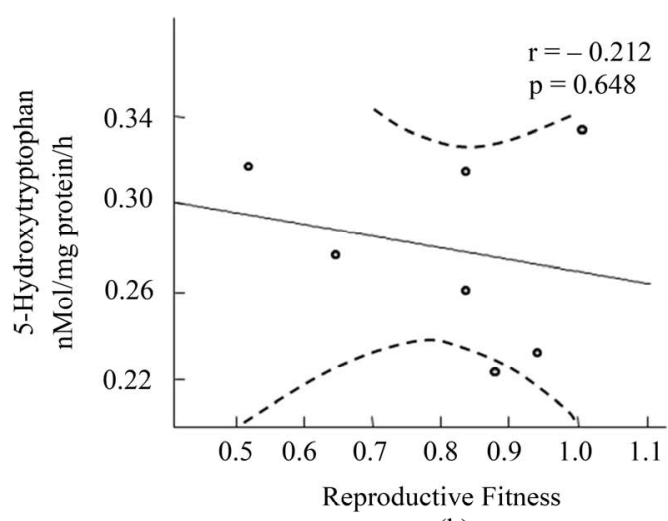

(b)

Figure 4. Graphs that show the results of the Pearson's Coefficient test depicting the interaction between epididymal serotonin concentration (a) or TPH activity (b) with reproductive fitness in copulator males.

productive fitness, offspring number, successful matings and seminal plug volume all correlated positivelywith epididymal serotonin concentrations. These results agree with the notion that the epididymis evolved to improve paternity in mammalian males [21].
A puzzling observation that arises from our experiments is that the prostatic concentration of serotonin was higher in copulator than in non-copulator males, in spite of the fact that TPH activity was remarkably low in both animal groups. These results suggest that serotonin is not 
Epididymis
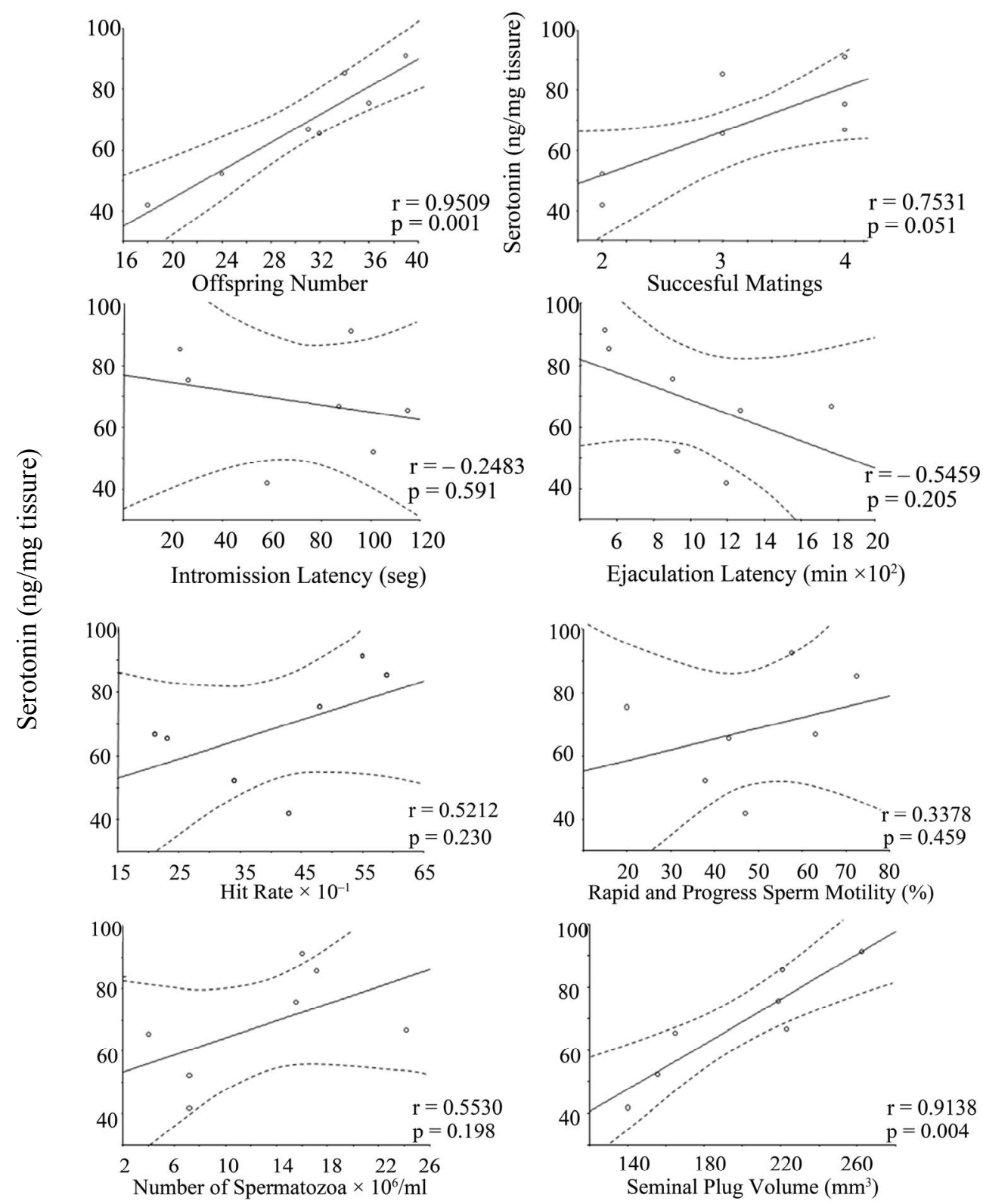

Figure 5. Graphs that show the results of the Pearson's Coefficient test depicting the interaction between epididymal serotonin concentration with parameters that monitor fertility and sexual performance in copulator males.

In agreement with this inference, it is long known that the prostate comprises a group of neuroendocrine cells distributed throughout its interstitial space or intermingled among epithelial cells [22]. Neuroendocrine cells have the ability to uptake serotonin to later release it. So, neuroendocrine cells could make available serotonin in the prostate. Interestingly, it is known that the number of these cells is higher in male rodents kept as breeders [23].

Several intriguing aspects emerge from the correlation studies carried out in copulator males:

1) The volume of the seminal plug correlates with fertility in male rats $[24,25]$. Traditionally, the formation of this structure is ascribed to the sexual accessory glands $[25,26]$. This is why it is surprising that seminal plug volume and epididymal serotonin concentrations correlated positively in our analyses. The epididymis, however, produces a variety of proteins that could facilitate, in addition to improving the capacity of sperm to fertilize ova $[27,28]$, the formation of seminal plugs. Fur- 
thermore, the release of epididymal secretory products is modulated by serotonin [29]. Hence, increments in epididymal serotonin availability could be associated with factors that control seminal plug volume.

2) Epididymal serotonin concentration did not correlate with sperm motility or sperm concentration. This is intriguing because serotonin increases sperm motility and concentration [30,31] and the epididymis is the organ from which sperms are ejaculated. We believe the discrepancy may reflect technical limitations. For instance, although the chromatographic analyses carried out in our work clearly portrait serotonin availability in the organ as a whole, they do not allow estimations of the amount released into the ductal system. In addition, female factors could modulate sperm parameters [32-34] regardless of the availability of serotonin in the epididymis; sperm samples were taken from the uterine horns.

3) Lastly, the lack of a positive or negative correlation between testicular serotonin and fertility/reproductive fitness in copulator males was also unexpected. It is known that increased production of spermatozoa provides reproductive advantages to males [19], that testicular serotonin concentration is increased in breeder rats [7] and that serotonin modulates spermatogenesis [35] and testosterone production and release from Leydig cells [14,36,37], a hormone long known to promote spermatogenesis [38] and sexual behavior [39]. Up to now, we have no explanation for this counterintuitive outcome. We believe, however, that female factors may also explain these observations.

In spite of the unexpected results, we believe that our observations support that copulator and non-copulator male rats feature a distinct serotoninergic tone in the epididymis, testicle and ventral prostate gland, and that the increment of this trait in copulator males probably is associated with greater sexual experience. In the future it would be fundamental to evaluate whether non-copulator males lack or have a diminished ability to display adaptive plasticity when sexually trained for longer times. Finally, the observation documenting that epididymal serotonin concentration correlated with parameters that monitor male fertility and reproductive fitness in copulator males predicts that epididymal factors increase their chances of parenting offspring.

\section{ACKNOWLEDGEMENTS}

Authors are grateful to Patricia Padilla Cortés, Jesús Ramírez Santos, Luz Lilia Jiménez, Rico, Georgina Díaz Herrera, Alfonso Malagón Mendiola, Raymundo Reyes and Marta Carrasco for their valuable technical, administrative assistance and animal care. We are indebted to Dr. John McHaffie for helpful criticisms and manuscript editing. This work was supported by a grant from the Dirección General de
Asuntos del Personal Académico, Universidad Nacional Autónoma de México (PAPIIT IN215208). AIPC, JLTL and MLMC are fellows from the Consejo Nacional de Ciencia y Tecnología.

\section{REFERENCES}

[1] Pfaus, J.G., Kippin, T.E. and Centeno, S. (2001) Conditioning and sexual behavior: A review. Hormones and Behavior, 40, 291-321. doi:10.1006/hbeh.2001.1686

[2] Whalen, R.E., Beach, F.A. and Kuehn, R.E. (1961) Effects of exogenous androgens of sexually responsive and unresponsive male rats. Endocrinology, 69, 373-380. doi:10.1210/endo-69-2-373

[3] Portillo, W. and Paredes, R.G. (2003) Sexual and olfactory preference in non copulating male rats. Physiology and Behavior, 80, 155-162.

doi:10.1016/S0031-9384(03)00231-2

[4] Portillo, W. and Paredes, R.G. (2004) Sexual incentive motivation, olfactory preference and activation of the vomeronasal projection pathway by sexually relevant cues in non-copulating and naive male rats. Hormones and Behavior, 46, 330-340.

doi:10.1016/j.yhbeh.2004.03.001

[5] Portillo, W., Diaz, N.F., Cabrera, E.A., Fernandez-Guasti A. and Paredes, R.G. (2006) Comparative analysis of inmunoreactive cells for androgen receptors and oestrogen receptor $\alpha$ in copulating and non copulating male rats. Journal of Neuroendocrinology, 18, 168-176. doi:10.1111/j.1365-2826.2005.01401.x

[6] Portillo, W., Castillo, C.G., Retana-Márquez, S., Roselli, C.E. and Paredes, R.G. (2007) Neuronal activity of aromatase enzyme in non copulatory male rats. Journal of Neuroendocrinology, 19, 139-141. doi:10.1111/j.1365-2826.2006.01513.x

[7] Jiménez-Trejo, F., Tapia-Rodríguez, M., Queiroz, D.B., Padilla, P., Avellar, M. C., Manzano, P.R., Manjarrez, G. and Gutiérrez-Ospina, G. (2007) Serotonin concentration synthesis cell origin and targets in the rat caput epididymis during sexual maturation and variations associated whit adult mating status: Morphological and biochemical studies. Journal of Andrology, 28, 136-149.

[8] Frungeri, M.B., Gonzalez-Calvar, S.I., Rubio, M., Ozu, M., Lustig, L. and Calandras, R.S. (1999) Serotonin in golden hamster testes: Testicular levels, inmunolocalization and role during sexual development and photoperiodic regression-recrudescence transition. Neuroendocrinology, 69, 299-308. doi:10.1159/000054431

[9] Chaturvedi, C.M. and Singh, A.B. (1992) Suppression of annual testicular development in Indian palm squirrel, Funambulus pennati by $8 \mathrm{hrs}$ temporal relationship of serotonin and dopamine precursor drugs. Journal of Neural Transmission, 88, 53-60. doi:10.1007/BF01245036

[10] Kim, S.W. and Paick, J.S. (2004) Peripheral effects of serotonin on the contractile responses of rat seminal vesicles and vasa deferentia. Journal of Andrology, 25, 893899.

[11] Piner, J., Sutherland, M., Millar, M., Turner, K., Newall, D. and Sharpe, R.M. (2002) Changes in vascular dynamics of the adult rat testis leading to transient accumulation 
of seminiferous tubule fluid after administration of a novel 5-hidroxycriptamine (5-HT) agonist. Reproductive Toxicology, 16, 141-150. doi:10.1016/S0890-6238(02)00008-4

[12] Leung, G.P., Dun, S.L., Dun, N.J. and Wong, P.Y. (1999) Serotonin via 5-HT1B and 5-HT2B receptors stimulates anion secretion in the rat epididimal epithelium. Journal of Physiology, 519, 657-667. doi:10.1111/j.1469-7793.1999.0657n.x

[13] Killam, A.L., Watts, S.W. and Cohen, M.L. (1995) Role of the alpha 1-adrenoreceptors and 5-HT2 receptors in serotonin-induced contraction of rat prostate: Autoradiographical and functional studies. European Journal of Pharmacology, 273, 7-14. doi:10.1016/0014-2999(94)00613-C

[14] Gerendai, I., Banzerowski, P., Csernus, V. and Halasz, B. (2007) Innervation and serotoninergic receptors of the testis interact with local action of interleukin-1beta on steroidogenesis. Autonomic Neuroscience, 131, 21-27. doi:10.1016/j.autneu.2006.06.002

[15] Das, T.K., Mazumder, R. and Biswas, N.M. (1982) Spermatogenesis in rat: Effect of L-typtophan loading. Andrologia, 14, 242-249.

[16] Lucio, R.A., Tlachi, J.L., López, A.A., Zempoalteca, R. and Velázquez-Moctezuma, J. (2009) Analisis of the parameters of the ejaculate in the laboratory wistar rat: Technical description. Veterinaria México, 40, 205-215.

[17] Lucio, R.A., Manzo, J., Martínez-Gómez, M., Sachs, B.D. and Pacheco, P. (1994) Participation of pelvic nerve in male rat copulatory behavior. Physiology and Behavior, 55, 241-246. doi:10.1016/0031-9384(94)90129-5

[18] Portillo, W. and Paredes, R.G. (2009) Conditioned place preference induced by morphine in non-copulating male rats. Behavioral Brain Research, 203, 308-311.

[19] Ramm, S.A. and Stockley, P. (2009) Adaptative plasticity of mammalian spremproduction in response to social experience. Proceedings of the Royal Society B: Biological Sciences, 276, 741-755. doi:10.1016/j.bbr.2009.04.037

[20] Lemaitre, J.F., Ramm, S.A., Horst, J.L. and Stockley, P. (2010) Social cues of sperm competition influence accessory reproductive gland size in a promiscuous mammal. Proceedings of the Royal Society B: Biological Sciences, Epub ahead of print. http://rspb.royalsocietypiblishing.org/conten/early/2010/0 9/24/rspb..1828.long

[21] Jones, R.C. (1998) Evolution of the vertebrate epididymis. Journal of Reproduction and Fertility Supplement, 53, 163-182.

[22] Rodríguez, R., Pozuelo, J. M., Martin, R., Henriques-Gil, N., Haro, M., Arriazu, R. and Santamaria, L. (2003) Presence of neuroendocrine cells during postnatal development in rat prostate: Immunohistochemical, molecular and quantitative study. Prostate, 57, 176-185.

[23] Di Sant'Agnese, P.A., Davis, N.S., Chen, M. and De Mesy Jensen, K.L. (1987) Age-related changes in the neuroendocrine (endocrine-paracrine) cell population and the serotonin content of the guinea pig prostate. Laboratory Investigation, 57, 729-736.

[24] Mathews, M. and Adler, N.T. (1977) Facilitative and inhibitory influences of reproductive behavior on sperm transport in rats. Journal of Comparative and Physio- logical Psychology, 91, 727-741. doi: $10.1037 / \mathrm{h} 0077364$

[25] Carballada, R. and Esponda, P. (1992) Role of fluid from seminal vesicles and coagulating glands in sperm transport into the uterus and fertility in rats. Journal of Reproduction and Fertility, 95, 639-648. doi:10.1530/jrf.0.0950639

[26] Cukierski, M.A., Sina, J.L., Prahalada, S. and Robertson, R.T. (1991) Effects of seminal vesicle and coagulating gland ablation on fertility in rats. Reproductive Toxicology, 5, 347-352. doi:10.1016/0890-6238(91)90093-U

[27] Jones, R.C., Dacheux, J.L., Nixon, B. and Ecroyd, H.W. (2007) Role of the epididymis in sperm competition. Asian Journal of Andrology, 9, 493-499. doi:10.1111/j.1745-7262.2007.00284.x

[28] Zhou, Y., Zheng, M., Shi, Q., Zhang, L., Zhen, W., Chen, W. and Zhang, Y. (2008) An epididymis-specific secretory protein hongrES1 critically regulates sperm capacitation and male fertility. PLOS ONE, 3, 12. doi:10.1371/journal.pone.0004106

[29] Leung, G.P., Dun, S.L., Dun, N.J. and Wong, P.Y. (1999) Serotonin via 5-HT1B and 5-HT2B receptors stimulates anion secretion in the rat epididymal epithelium. The Journal of Physiology, 519, 657-670. doi:10.1111/j.1469-7793.1999.0657n.x

[30] Parisi, E., De Prisco, P., Capasso, A. and Del Prete, M. (1984) Serotonin and sperm motility. Cell Biology International Reports, 8, 95.

[31] Waldinger, M.D., Berendsen, H.H.G., Blok, B.F.M., Olivier, B. and Holstege, G. (1998) Premature ejaculation and serotonergic antidepressants-induced delayed ejaculation: the involvement of the serotonergic system. Behavioral Brain Research, 92, 111-118. doi:10.1016/S0166-4328(97)00183-6

[32] Wilson, N., Tubman, S.C., Eady, P.E. and Robertson, G.W. (1997) Female genotype affects male success in sperm competition. Proceedings of the Royal Society B: Biological Sciences, 264, 1491-1495. doi:10.1098/rspb.1997.0206

[33] Ball, M.A. and Parker, G.A (2003) Sperm competition games: sperm selection by females. Journal of Theoretical Biology, 224, 27-42. doi:10.1530/rep.1.00598

[34] Coria-Ávila, G.A., Jones, S.L., Solomon, C.E., Gavrila, A.M., Jordan, G.J. and Pfaus, J.G. (2006) Conditioned partner preference in female rats for strain of male. Physiology and Behavior, 88, 529-537.

[35] Aragon, M.A., Ayala, M.E., Marin, M., Aviles, Damian-Matsumara, A.P. and Rodriguez, R. (2005) Serotoninergic system blockage in the prepubertal rat inhibits spermatogenesis development. Reproduction, 129, 717727.

[36] Csaba, C., Csernus, V. and Gerendai, I. (1998) Intratesticular serotonin affects stereidogenesis in the rat testis. Journal of Neuroendocrinology, 10, 371-376.

[37] Frungieri, M.B., Zita, K., Pignataro, O.P., GonzalezCalvar, S.I. and Calandra, R.S. (2002) Interactions between testicular serotoninergic, catecolaminergic and corticotropi-releasing hormone systems modulating cAMP and testosterone production in the Golden Hamster. Neuroendocrinology, 76, 35-46. doi: $10.1159 / 000063682$

[38] Cheng, C.Y. and Mruk, D.D. (2010) A local autocrine 
axis in the testes that regulates spermatogenesis. Nature Reviews Endocrinology, 6, 380-395.

doi:10.1038/nrendo.2010.71

[39] Buvat, J., Maggi, M., Gooren, L., Gudy, A.T., Kaufman, J.,
Morgentaler, A., Schulman, C., Tan, H.M., Torres, L.O., Yassin, A. and Zitzmann, M. (2010) Endocrine aspects of male sexual dysfunctions. Journal of Sex Medicine, 7, 1627-1656. doi:10.1111/j.1743-6109.2010.01780.x 